\title{
In situ characterization of stem cells-like biomarkers in meningiomas
}

\author{
Hanin Alamir ${ }^{1 \dagger}$, Mona Alomarii ${ }^{2 \dagger}$, Abdulla Ahmed A. Salwati ${ }^{2}$, Mohamad Saka ${ }^{2}$, Mohammed Bangash ${ }^{3}$, \\ Saleh Baeesa ${ }^{3}$, Fahad Alghamdi ${ }^{4}$, Angel Carracedo ${ }^{5,6}$, Hans-Juergen Schulten ${ }^{6}$, Adeel Chaudhary ${ }^{1,6,7}$, \\ Adel Abuzenadah ${ }^{1,2,7}$ and Deema Hussein ${ }^{2^{*}}$ (1)
}

\begin{abstract}
Background: Meningioma cancer stem cells (MCSCs) contribute to tumor aggressiveness and drug resistance. Successful therapies developed for inoperable, recurrent, or metastatic tumors must target these cells and restrict their contribution to tumor progression. Unfortunately, the identity of MCSCs remains elusive, and MSCSs' in situ spatial distribution, heterogeneity, and relationship with tumor grade, remain unclear.

Methods: Seven tumors classified as grade II or grade III, including one case of metastatic grade III, and eight grade I meningioma tumors, were analyzed for combinations of ten stem cell (SC)-related markers using immunofluorescence of consecutive sections. The correlation of expression for all markers were investigated. Three dimensional spatial distribution of markers were qualitatively analyzed using a grid, designed as a repository of information for positive staining. All statistical analyses were completed using Statistical Analysis Software Package.

Results: The patterns of expression for SC-related markers were determined in the context of two dimensional distribution and cellular features. All markers could be detected in all tumors, however, Frizzled 9 and GFAP had differential expression in grade II/III compared with grade I meningioma tissues. Correlation analysis showed significant relationships between the expression of GFAP and CD133 as well as SSEA4 and Vimentin. Data from three dimensional analysis showed a complex distribution of SC markers, with increased gene hetero-expression being associated with grade II/III tumors. Sub regions that showed multiple co-staining of markers including CD133, Frizzled 9, GFAP, Vimentin, and SSEA4, but not necessarily the proliferation marker Ki67, were highly associated with grade II/III meningiomas.

Conclusion: The distribution and level of expression of CSCS markers in meningiomas are variable and show heteroexpression patterns that have a complex spatial nature, particularly in grade II/II meningiomas. Thus, results strongly support the notion of heterogeneous populations of CSCS, even in grade I meningiomas, and call for the use of multiple markers for the accurate identification of individual CSC subgroups. Such identification will lead to practical clinical diagnostic protocols that can quantitate CSCs, predict tumor recurrence, assist in guiding treatment selection for inoperable tumors, and improve follow up of therapy.
\end{abstract}

Keywords: Meningioma, Cancer stem cells, Immunofluorescence, CD133, SOX2, Nestin, Frizzled 9, GFAP, SSEA4, Olig2

\footnotetext{
*Correspondence: deemah@hotmail.com; dmhussein@kau.edu.sa

${ }^{\dagger}$ Hanin Alamir and Mona Alomari are first co-authors

2 King Fahd Medical Research Center, King Abdulaziz University, P.O. Box.

80216, Jeddah 21589, Saudi Arabia

Full list of author information is available at the end of the article
} 


\section{Background}

Meningiomas occur in multiple extra-axial locations within arachnoid membranes and are highly frequent compared with other types of central nervous system tumors (CNSTs) [1-3]. Genetic analyses of bulk meningioma tissues identified mutations in several pathways including the phosphoinositide 3-kinase (PI3K) and the $\mathrm{G}$ protein-coupled receptor smoothened (SMO) signaling pathways [4-6]. Histopathologically, these tumors are classified by the World Health Organization (WHO) into 15 variants within grades I to III. Unfortunately, up to $20 \%$ of grade I tumors reoccur, and apart from Mib-1, molecular markers that enable prediction of recurrence have not been established $[3,7,8]$.

Meningiomas have been shown to harbor cancer stem cells (CSCs), highly resilient cancer cells that employ deregulated stem cell (SC) expression profiles and are capable of causing reoccurrence [9-14]. Targeting CSCs is predicted to enhance therapy outcomes [3]. A range of genes and their proteins have been associated with the identity of CNST CSCs. CD133/Prominin-1, a five-transmembrane glycoprotein, is normally expressed in embryonic neural SC radial glial/ependymal cells and in ependymal cells in the adult brain [15]. The protein is thought to interact with selected gangliosides to modulate cell-to-cell contact in a cell cycle-related manner $[16,17]$. In CNSTs, high CD133 expression has been associated with poor survival [1821]. In meningioma cell lines, higher CD133 expression correlates positively with cell proliferation and drug resistance $[9,13,22,23]$.

The expression of Nestin, a type VI intermediate filament, has been shown to be important CSC marker for CNST growth, migration, and invasion [24-26], possibly by influencing the cell cycle [27]. Higher expression of Nestin has been detected in grades II and III meningiomas compared to grade I [28]. The deregulated expression of the transcription factor SOX2 has also been observed in several CNST CSCs [29-32]. The knockdown of SOX2 was shown to slow the growth and proliferation of GBM CSCs [33]. In GBM cells positive for CD133, silencing SOX2 impaired tumor initiation and drug resistance [34]. Frizzled 9 (FZD9) belongs to the frizzled protein family, trans-membrane signaling molecules that act as receptors for the WNT protein, and plays a key role in cell development by maintaining planer cell polarity [35]. Mutations in FZD/WNT genes are linked to several malignancies [36]. In astrocytoma and glioblastoma, FZD9 is predominantly expressed by neoplastic cells, and its expression is positively correlated with WHO grading and Ki-67 positivity [37]. Inhibiting the FZD family in glioblastoma cell lines leads to increased differentiation [38].
Stage-specific embryonic antigen-4 (SSEA4), also known as FUT4 and CD15, is a glycosphingolipid (GSL) containing a terminal sialic acid residue ( $N$-acetylneuraminic acid) and is involved in the globo-series ganglioside synthesis. SSEA4 is highly expressed during the preimplantation stage in germ cells in the testis and ovaries, and is down-regulated upon differentiation [39-41]. Targeting SSEA4 in vitro suppressed the growth of GBM cell lines [42], and cells positive for SSEA4 have a higher capability for metastasis and invasion [43-47]. Olig2 is a basic helix-loop-helix (bHLH) transcription factor that is expressed in oligodendrocytes and in oligodendritic progenitor cells [48-50]. The protein was shown to mediate the proliferation, migration, and invasion of both normal astrocytes and malignant GBM cells [50-53].

Proteins associated with the differentiation of SCs include Vimentin, glial fibrillary acidic protein (GFAP), and beta III tubulin ( $\beta$ III-tubulin/ $\beta$ IIIT). Vimentin is a class III intermediate protein that is expressed in mesenchymal cells. The protein's main function is to support the cytoskeleton [54], and it is highly associated with meningiomas [55]. GFAP is a class III intermediate filament protein, with five different isoforms (GFAP $\alpha$, GFAP $\beta$, GFAP gamma $\gamma$, GFAP $\delta$, and GFAP $k$ ), and was shown to be expressed in the astrocyte lineage during the development of the CNS $[56,57]$. BIII-Tubulin is a neuron-specific microtubule required for neuronal axon guidance, maintenance, and development [58]. Mutations in the $\beta$ III-tubulin gene result in multiple disorders of the CNS [59], and high protein expression is frequently detected in several CNSTs [60]. Although not limited to the identity of CSCs, these markers are frequently associated with it, and their expressions vary according to tumor type and progression [61]. Importantly, recent evidence has indicated that the hetero-identity of CSCs can be detected even within a single tumor developed in a patient $[62,63]$.

Previously, we published gene expression profiles for most of the meningioma patients' tissues collected for our cohort [64, 65], as well as for their corresponding cell lines [22]. For this work, we aimed to determine the hetero-dynamic characteristics of MCSCs in situ and identify differential patterns associated with grades II/III tumors.

\section{Methods \\ Sample collection}

Meningioma specimens collected between February 2013 and December 2015 were obtained within 30 min of tumor removal and frozen immediately at $-80^{\circ} \mathrm{C}$. Neuropathologists diagnosed surgical specimens according to WHO classification. The clinical profiles for the included patients and their tumors' histopathological features are 
shown in Additional file 1: Table S1. Additional file 2: Figure $\mathrm{S} 1$ shows $\mathrm{H} \& \mathrm{E}$ representative sections of histological variants of meningiomas included in this work, as well as atypical features. The expression profiles for prevalent cancer driver genes [66], extracted from aforementioned publications, are shown in Additional file 3: Table S2.

\section{Cyrovial sectioning}

Each frozen tissue was cryosectioned to generate 10 consecutive sections at a thickness of $4 \mu \mathrm{m}$. Slides of sections were stored at $-20{ }^{\circ} \mathrm{C}$ until processed for immunofluorescence.

\section{Immunofluorescence staining}

Sections were left at room temperature for $5 \mathrm{~min}$ to defrost, and tissues were enclosed with wax to retain solutions. Then, they were washed five times for $5 \mathrm{~min}$ in phosphate buffered saline (PBS). Sections were fixed with $4 \%$ formalin for $10 \mathrm{~min}$, then washed three times for 5 in with PBS. Sections were permeabilized, blocked for non-specific antigens with freshly made blocking reagent ( $5 \%$ normal goat serum, $0.25 \%$ Triton X-100 in PBS), and incubated for $1 \mathrm{~h}$ at room temperature. Single or double primary antibodies solutions (Antibodies, 2\% NGS, $0.25 \%$ Triton X-100 in PBS) were added to each section, and sections were incubated in a humidity chamber over night at $4{ }^{\circ} \mathrm{C}$. The following day, sections were washed three times for $10 \mathrm{~min}$ with $0.25 \%$ Triton X-100 in PBS (PBST) before incubating them with a secondary antibodies solution (488 goat anti-mouse (1:300, ab150105, abcam) and 555 goat anti-rabbit (1:700, ab150074, abcam) for $1 \mathrm{~h}$ in the dark at room temperature. Sections were then washed five times for 5 min with PBST. PBST was removed, and a drop of Vectashield with DAPI was added to each section to stain nuclei. For each tissue, sections were stained in the following order: secondary only (negative control); mouse anti-Nestin (1:50, ab6142, abcam) with rabbit anti-Ki67 (1:200, ab16667, abcam); mouse anti-CD133 (1:100, 130-092-395, Miltenyi) with rabbit anti-SOX2 (1:200, 09-0024, Stemgent); mouse anti-Vimentin (1:100, ab8978, abcam) with rabbit anti-Frizzled 9 (1:100, ab150515, abcam); rabbit anti-GFAP (1:500, ab7260, abcam); rabbit anti-beta III Tubulin (1:500, ab18207, abcam), mouse anti-SSEA4 (1:100, ab16287, abcam) with rabbit anti-SOX2 (1:200, 130-095-636, Miltenyi); and mouse anti-SSEA4 (1:100, ab16287, abcam) with rabbit anti-Olig2 (1:500, Ab42453, abcam). Processed slides were stored at $4{ }^{\circ} \mathrm{C}$.

\section{Image acquisition, enhancement, and counting}

All images were taken within the first 2 weeks after staining. For each section, five coordinate-fixed dispersed regions were selected to image. Pictures were taken at $20 \times$ magnifications using a Leica DMI6000 microscope and Leica DFC425 camera. Photos for individual channels were combined in Photoshop 7.0.1. Enhancements of the images were constrained by signal levels of negative controls of secondary antibodies only. Due to the complexity of staining features, co-positive, mono-positive, and negative cells were manually counted for each region within each section using Photoshop 7.0.1. Manual counting was performed twice by two independent scientists, and indications for positivity for each marker and final counts were confirmed with a neuropathologist. Images for Ki67 stained sections were also counted by an independent third person using automated counting in Image J software for analysis. Images were masked to count nuclei positive for Ki67, and counts were produced using ICTN plugin.

\section{Statistical analysis of the data}

The results were analyzed using SPSS version 21.0 to generate descriptive and inferential statistics. The differences between the manual and automated counts for Ki67 were analyzed using t-tests. The differences for the counts of expressions between grades and the differences in the number of identified unique sub-regions between individual tumors were explored using analysis of variance (ANOVA) robust tests of equality of means, and P-values for Welch and Brown-Forsythe were indicated. Correlations for markers' expressions across consecutive tumor sections were analyzed using Spearman's Rho correlation. $\mathrm{Chix}^{2}$ was used to test for the significance between grades for individual sub-regions.

\section{Results}

In situ features of SC associated markers in meningiomas

The patterns of expressions for all utilized markers were observed in meningioma tissues (Fig. 1). Positively stained cells for nuclear Ki67 were consistently dispersed as single cells within individual tumor sections. Cells positive for nuclear SOX2 and cytoplasmic FZD9 were consistently seen in niche-stained foci, while cells positive for cytoplasmic Vimentin were detected in large positive regions and had homo-expression patterns. Cells positive for Nestin, CD133, GFAP, BIIIT, SSEA4, and Olig2 had a tumordependent pattern of expression, which did not have a dichotomous association with grade. Membranous CD133 was detected in 12 tumors, and Olig2 could be seen at the nuclear envelope, as well as the nucleus, in all tumors.

\section{Evaluation of the average expressions for single proteins in grade I and grade II/III meningiomas identified GFAP and FZD9 as significant differential markers}

Data for Ki67 counts showed no significant difference between the manual and automated method ( $T$ test, $\mathrm{P}=0.5$ ), Additional file 4: Figure $\mathrm{S} 2$, supporting the use 


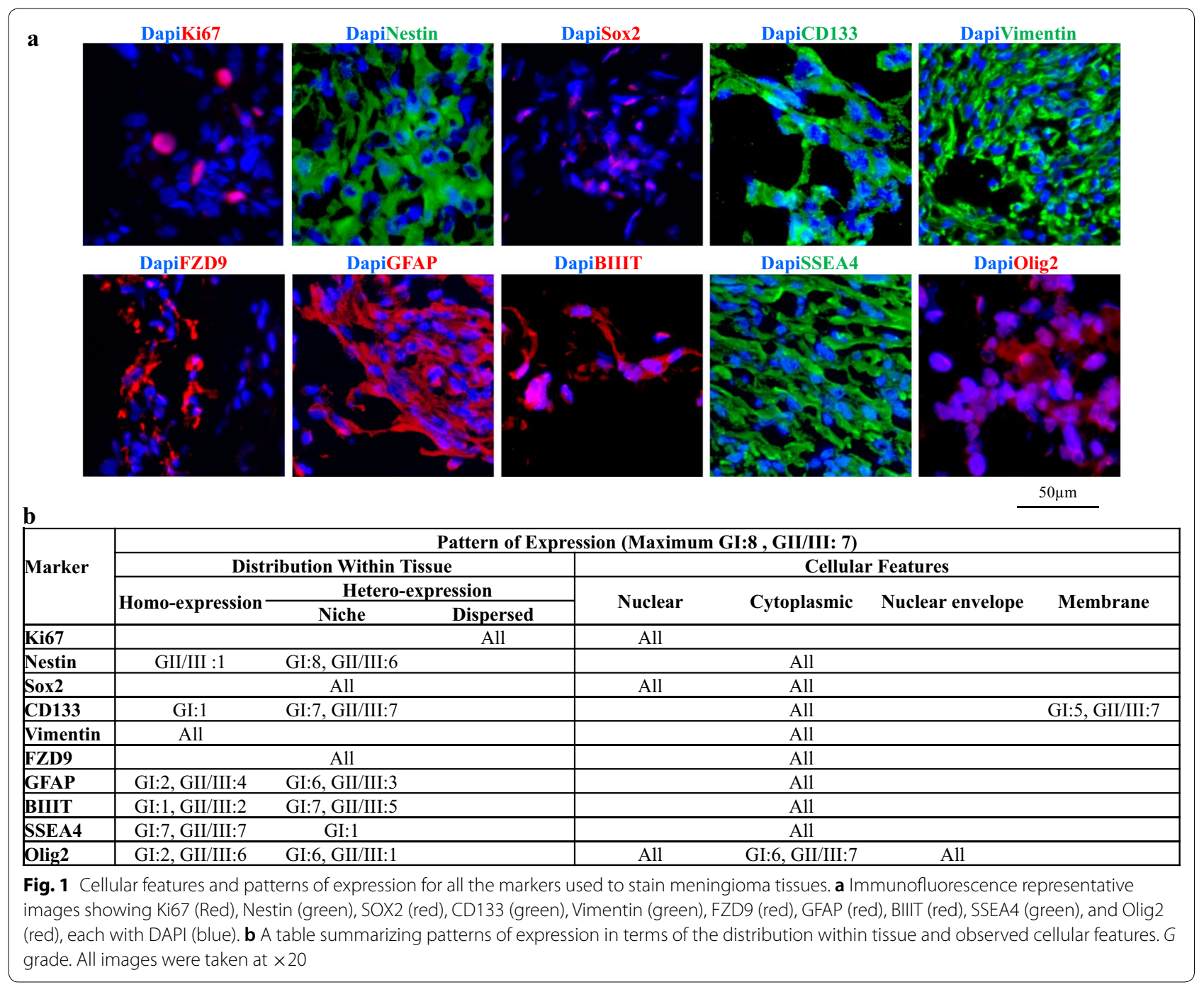

of manual counting for other markers that were complex to assess using automate methods. The analysis of average counts for each single marker's positive staining for grade I and grade II/III tumors indicated Ki67+, Vimentin + , BIIITubulin + as differential markers (BrownForsythe ANOVA, $\mathrm{P}<0.05)$, respectively, as shown in Table 1 and Fig. 2. For highly significant grade-related differential markers, single positive staining of FZD9+ or GFAP+ was statistically significantly higher in grade II/III meningiomas (Brown-Forsythe ANOVA, $\mathrm{P}<0.01$ ). For double-staining analysis (Table 1 and Fig. 3), the most significant average count increase in grade II/III meningiomas was seen for Vimentin+FZD9+ (Brown-Forsythe ANOVA, $\mathrm{P}<0.01)$. The averages for cell count staining SSEA4+Olig2+, Nestin-Ki67+, or CD133-Sox+ were also higher in grade II/III meningiomas (Brown-Forsythe ANOVA, $\mathrm{P}<0.05)$, while the average for the number of CD133+Sox+ cells decreased in grade II/III compared to grade I meningiomas (Brown-Forsythe ANOVA, $\mathrm{P}<0.05)$.

\section{Consecutive sections have similar expressions for a single marker}

To determine the nature of the positive spatial distribution of a single marker throughout the depth of a tumor, the expression profile for both SSEA4 and SOX2 was determined in adjacent and distal consecutively sectioned immunofluorescence-processed tissues. Adjacent sections six and seven were stained to detect SSEA4, while distal sections two and six were stained to detect SOX2 (Fig. 4). The percentages of cells positive for SSEA4 in section six correlated with positive cells for SSEA4 in the adjacent section seven (Spearman's Rho correlation coefficient $=0.687, \quad \mathrm{P}<0.001$ ). Similarly, the percentages of cells positive for SOX2 in section two correlated with positive cells for SOX2 in the distal section 
Table 1 The means of expressions, standard errors, and ANOVA P values for grade I versus grade II/III tumors for single and double-stained markers

\begin{tabular}{|c|c|c|c|c|}
\hline Marker(s) & Grade & Mean & STD error & $P$ value \\
\hline \multirow[t]{2}{*}{ Nestin+ } & Gl & 29.45 & 5.70 & 0.231 \\
\hline & $G\|/\| \|$ & 39.22 & 5.73 & \\
\hline \multirow[t]{2}{*}{$\mathrm{Ki} 67+$} & Gl & 0.77 & 0.17 & $0.019^{*}$ \\
\hline & $G\|/\| \|$ & 2.72 & 0.78 & \\
\hline \multirow[t]{2}{*}{ CD133+ } & Gl & 36.60 & 6.22 & 0.770 \\
\hline & $G\|/\| \|$ & 39.11 & 5.86 & \\
\hline \multirow[t]{2}{*}{ Sox2+ } & Gl & 12.45 & 2.76 & 0.929 \\
\hline & $G\|/\| I \|$ & 12.82 & 3.22 & \\
\hline \multirow[t]{2}{*}{ Vimentin+ } & Gl & 83.13 & 4.31 & $0.016^{*}$ \\
\hline & $\mathrm{G}\|/\|$ & 94.56 & 1.57 & \\
\hline \multirow{2}{*}{ Frizzled9+ } & Gl & 11.82 & 2.35 & $0.000^{* *}$ \\
\hline & $G\|/\| \|$ & 31.23 & 4.10 & \\
\hline \multirow[t]{2}{*}{ GFAP+ } & Gl & 49.11 & 5.80 & $0.000^{* *}$ \\
\hline & $\mathrm{G}\|/\| I \|$ & 78.03 & 3.28 & \\
\hline \multirow[t]{2}{*}{ BlIITubulin+ } & Gl & 30.65 & 5.16 & $0.033^{*}$ \\
\hline & $\mathrm{G}\|/\| / \|$ & 47.01 & 5.49 & \\
\hline \multirow[t]{2}{*}{ SSEA4+ } & Gl & 75.70 & 4.57 & 0.053 \\
\hline & GII/II & 87.11 & 3.57 & \\
\hline \multirow[t]{2}{*}{ Olig2+ } & Gl & 55.33 & 5.02 & 0.072 \\
\hline & $\mathrm{G}\|/\| / \|$ & 67.55 & 4.43 & \\
\hline \multirow[t]{2}{*}{ Nestin+Ki67+ } & Gl & 0.51 & 0.16 & 0.080 \\
\hline & $G\|/\| \|$ & 1.23 & 0.37 & \\
\hline \multirow[t]{2}{*}{ Nestin+Ki67- } & Gl & 28.94 & 5.59 & 0.258 \\
\hline & $\mathrm{G}\|/\| \|$ & 37.98 & 5.63 & \\
\hline \multirow[t]{2}{*}{ Nestin-Ki67+ } & Gl & 0.26 & 0.08 & $0.037^{*}$ \\
\hline & $\mathrm{G}\|/\| / \|$ & 1.49 & 0.56 & \\
\hline \multirow[t]{2}{*}{ CD133+Sox2+ } & Gl & 11.73 & 2.71 & $0.039^{*}$ \\
\hline & $\mathrm{G}\|/\|$ & 5.48 & 1.20 & \\
\hline \multirow[t]{2}{*}{ CD133+Sox2- } & Gl & 24.87 & 4.41 & 0.224 \\
\hline & GII/II & 33.63 & 5.61 & \\
\hline \multirow[t]{2}{*}{ CD133-Sox2+ } & Gl & 0.72 & 0.31 & $0.023^{*}$ \\
\hline & $\mathrm{G}\|/\| I \|$ & 7.35 & 2.77 & \\
\hline \multirow[t]{2}{*}{ Vimentin+FZD9+ } & Gl & 11.80 & 2.36 & $0.000^{* *}$ \\
\hline & $\mathrm{Gll/II}$ & 31.08 & 4.12 & \\
\hline \multirow[t]{2}{*}{ Vimentin+FZD9- } & $\mathrm{Gl}$ & 71.34 & 3.87 & 0.159 \\
\hline & $\mathrm{Gll/II}$ & 63.48 & 3.95 & \\
\hline \multirow[t]{2}{*}{ Vimentin-FZD9+ } & Gl & 0.03 & 0.02 & 0.125 \\
\hline & $\mathrm{G}\|/\|$ & 0.15 & 0.08 & \\
\hline \multirow[t]{2}{*}{ SSEA4+SOX2+ } & Gl & 12.57 & 2.50 & 0.565 \\
\hline & $G\|/\| I$ & 10.59 & 2.36 & \\
\hline \multirow[t]{2}{*}{ SSEA4+SOX2- } & Gl & 63.13 & 4.12 & $0.021^{*}$ \\
\hline & $\mathrm{G}\|/\| \|$ & 76.52 & 3.91 & \\
\hline SSEA4-SOX2+ & Gl & 0.07 & 0.05 & 0.539 \\
\hline & $G\|/\| \|$ & 0.03 & 0.03 & \\
\hline SSEA4+Olig2+ & Gl & 49.81 & 5.42 & $0.035^{*}$ \\
\hline & $\mathrm{G}\|/\| / \|$ & 64.64 & 4.29 & \\
\hline SSEA4+Olig2- & Gl & 29.15 & 3.51 & 0.324 \\
\hline & $\mathrm{G}\|/\|$ & 23.97 & 3.85 & \\
\hline SSEA4-Olig2+ & Gl & 5.52 & 2.95 & 0.405 \\
\hline & $\mathrm{G}\|/\| \|$ & 2.91 & 0.95 & \\
\hline
\end{tabular}

Table 1 (continued)

P values for ANOVA Welch and Brown-Forsythe are indicated

* P significant at the 0.05 level (2-tailed)

** $P$ is significant at the 0.01 level (2-tailed)

six (Spearman's Rho correlation coefficient $=0.749$, $\mathrm{P}<0.001)$.

There are significant correlations between the expressions of different SC associated markers across consecutive tissues

Since the expression profiles of each of SOX2 and SSEA4 were equivalently spatially distributed throughout consecutive sections of a tumor mass, correlations between the expressions of different single markers across all consecutive sections were investigated (Fig. 5). Expression data indicated a highly significant correlation between the expressions of Vimentin and SSEA4 and the expressions of CD133 and GFAP. Significant correlations were observed for the expressions of SSEA4 with CD133 or Nestin, and SOX2 with BIIIT. FZD9 also had significant correlations with Vimentin, SOX2 or with Olig2. The presence of Nestin-positive proliferating cells correlated with the presence of Vimentin+FZD9+ cells.

Qualitative analysis of sub-areas across consecutive sections show increased hetero-regional expression in grades $\mathrm{II} / \mathrm{III}$ meningiomas

To investigate the relationship between multiple markers across consecutive sections, images for a coordinate-fixed region within stained sections were scored using a grid with 96 sub-regions, each covering an area of $0.0037 \mathrm{~mm}^{2}$. The grid was used as a repository sheet of qualitative information for positive staining in each sub-area for all consecutive sections of each tumor, as exemplified in Fig. 6a, Additional file 5: Figure S3, and Additional file 6: Figure S4. Collectively, the data showed a complex distribution of the scoring of the combined SC associated markers, across individual tissues (208 unique combinations, Additional file 7: Table S3), with increased hetero-regional expression being associated with grade II/III meningiomas (ANOVA, $\mathrm{P}<0.01$, Fig. $6 \mathrm{~b}$ ). Interestingly, the level of hetero-regional expression separated tumors into three significantly different groups (ANOVA, $\mathrm{P}<0.01$ ), with all tumors in group 1 (R1) being grade I and all meningiomas in group 3 (R3) being grade II/III, while tumors in group 2 (R2) had mixed grades for I and II. Regions that were significantly frequently occurring in grade II/III but never in grade I meningiomas included those that were positive for $\mathrm{CD} 133+\mathrm{SOX} 2 \pm$ Vimentin+ FZD9+GFAP+BTIII+SSEA4+Olig2+, and Nestin+Ki6 
7+CD133+Vimentin+FZD9+GFAP+BTIII+SSEA4+O lig2+ (Fig. 6c, d).

\section{Discussion}

Collectively, meningiomas present a unique model for exploring tumor progression in CNSTs, as they encompass tumors with a variety of aggressiveness and grades. Our study sheds a light into the protein expression and co-localization of critical SC and developmental markers that are implicated in modulating malignancy. In particular, we present a comprehensive differential analysis of the three dimensional spatial distribution of SC markers in situ, their co-expression, and their correlation in relation to grade.

The features observed for individual proteins in the meningioma samples were consistent with their manufacturing data and previous publications in other tissue types [42, 57, 67-73]. Ki67-positive cells were clearly dispersed, indicating that dividing cells were not particularly grouped together. Both SOX2 and FZD9 were less frequent and occurred in niches, which is in concordant with niche-organized CSCs. All other studied markers had variable characteristics that had either niche, hetero-, or homo-expression, in a tumor-dependent manner. Of particular interest is the localization of Olig2. The exclusion of this protein from the nucleus has been reported to be associated with astrocyte differentiation, while nuclear Olig2 was shown to target chromatin remodelers, prior differentiation in oligodendrocyte progenitors [49, $53,74]$. In this cohort, Olig2 was predominantly observed in the nucleus, at the nuclear envelope, and only occasionally in the cytoplasm, thus implying that meningioma cells may behave like oligodendrocyte progenitors. However, further detailed work is required to clarify this

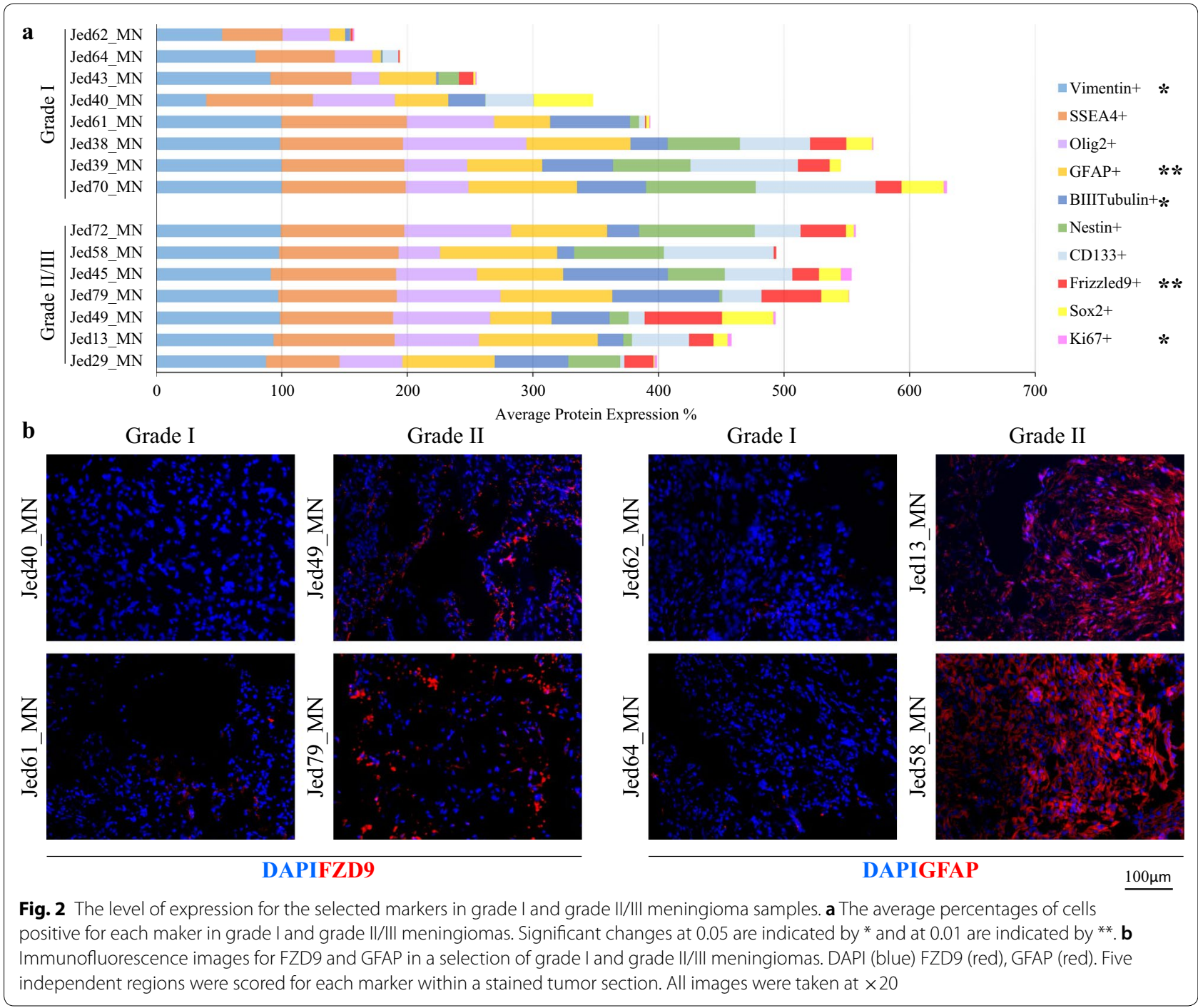




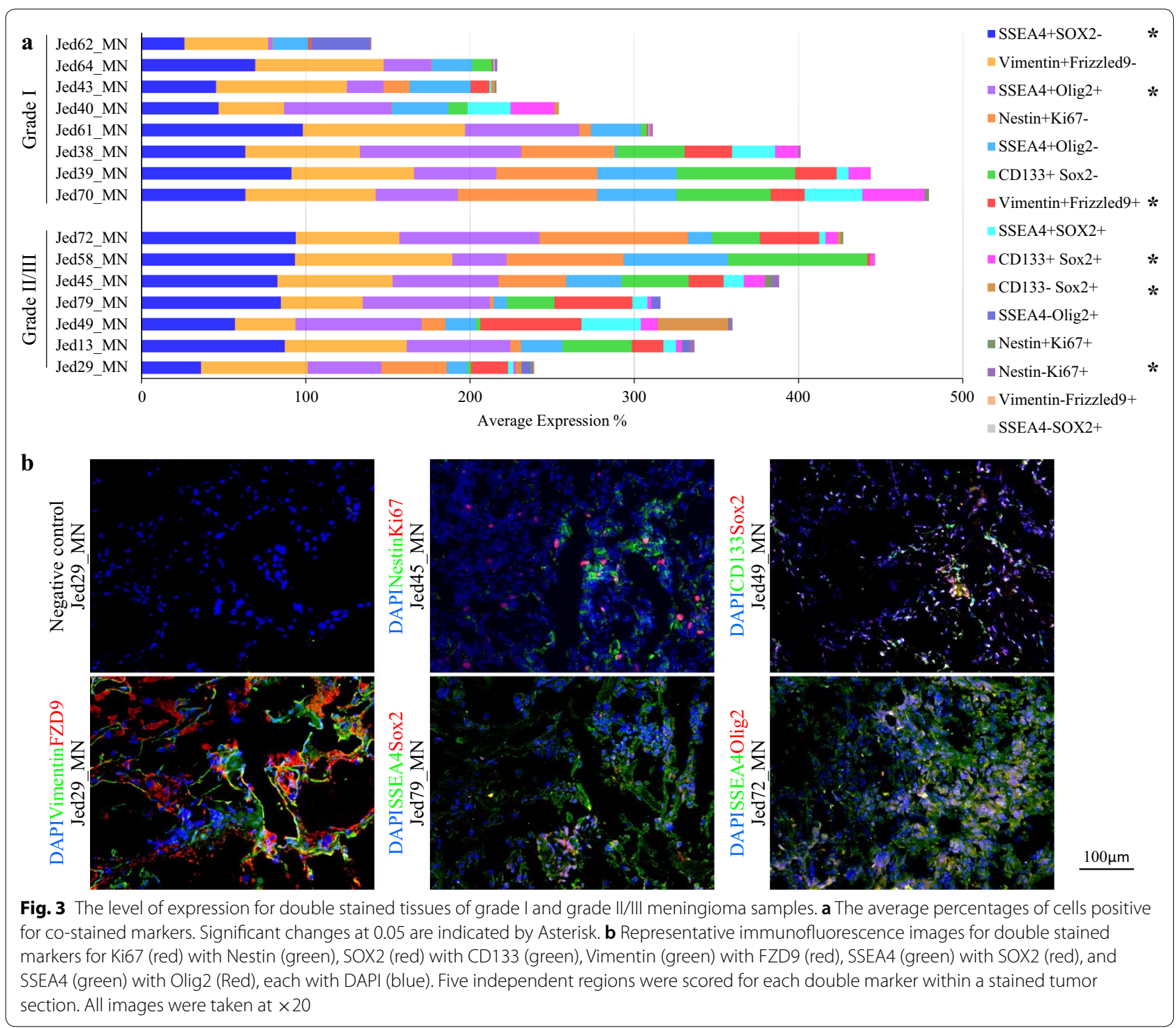

observation and future studies will need to be completed on a larger scale.

Notably, the expression of all individual proteins was not dichotomous for grade. Cells positive for all SC markers were detected in grade I meningiomas, suggesting that either the establishment of CSC clones occurs early in tumor development, or that by the time tumors become clinically evident, CSCs are already established. However, consistent with published data, a higher number of positive cells stained for Ki67 and Vimentin were detected in grade II/III compared with grade I meningiomas [13,69]. To the best of our knowledge, this study is the first to present in situ analysis of the expression of SSEA4, OLIG2 and FZD9 in meningiomas. Cells positive for SSEA4 and OLIG2 were more frequent in grade II/III meningiomas and the number of FZD9-positive cells was significantly higher in grade II/III meningiomas, although the overall levels remained relatively low, implying that growth of FZD9-positive cells in meningiomas is restricted.

Surprisingly, and in contrast to other studies, more cells positive for GFAP or BIIIT were detected in grade II/III meningiomas [75]. A form of GFAP that differs in the C-terminal domain was detected in the subventricular zone (SVZ) of the brain, suggesting that GFAP may not be an exclusive astrocytic differentiation marker [56, 57]. Indeed, it is important to consider that for proteins with multiple forms, the detection of a protein's expression using immunostaining will depend 
a DAPISSEA4

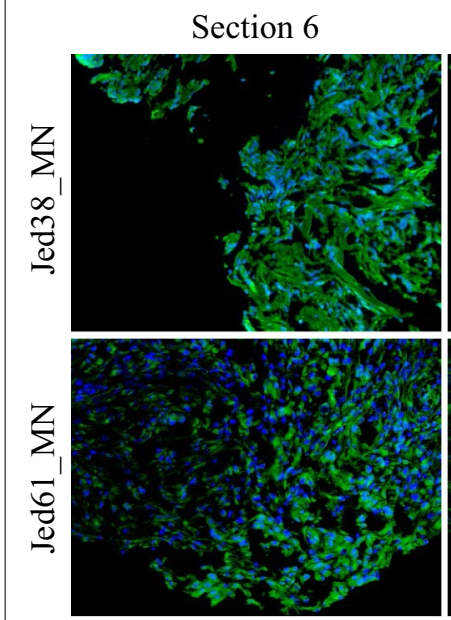

\section{Section 7}
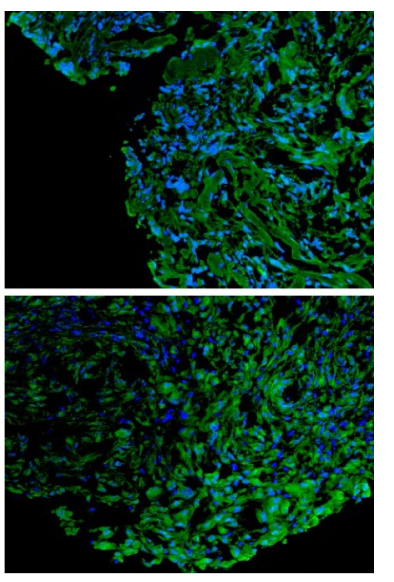

$100 \mu \mathrm{m}$

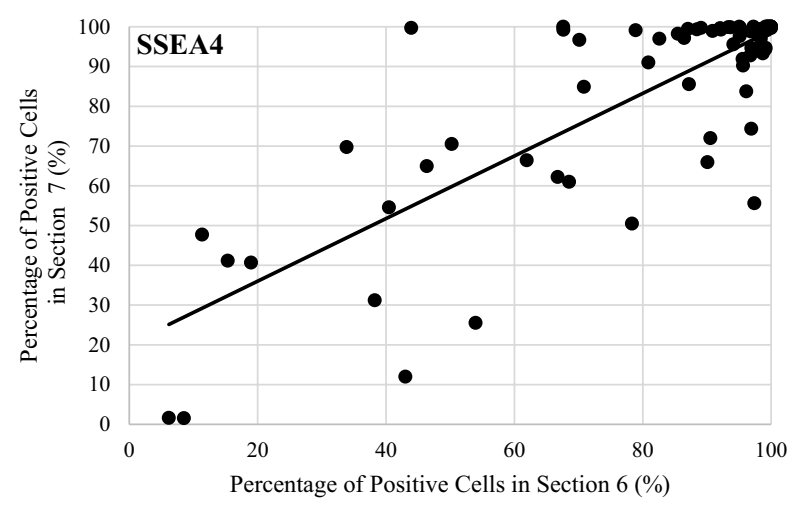

b DAPISox 2
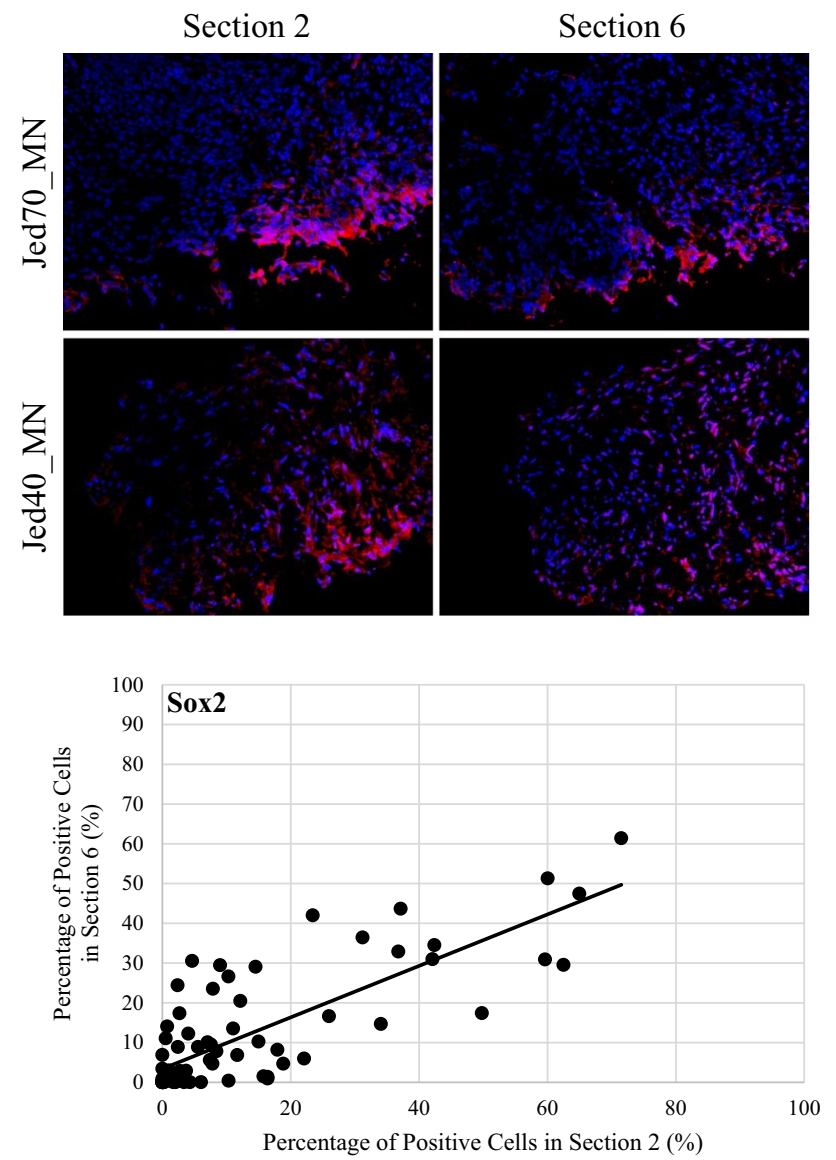

Fig. 4 The correlation of the expression of SSEA4 and SOX2 in adjacent and distal consecutively sectioned immunofluorescence-processed tissues. a Representative immunofluorescence images for adjacent sections 6 and 7 stained for SSEA4 (green), and for distal sections 2 and 6 stained for SOX2 (red). All images were taken at $\times 20$. b Graphs showing Spearman's Rho correlations between positive expression of SSEA4 in sections 6 and 7 or SOX2 in sections 2 and 7, for all samples

on the utilized antibody [76]. According to the manufacturing information sheet, the GFAP antibody used in this work was raised against the full length of a purified native protein corresponding to human GFAP.

Compared to previous studies $[10,13,28,67,68,77$, 78], co-staining for SOX2, CD133 and Nestin across a single section also provided a few unexpected observations. In particular, the average number of cells positive for both SOX2 and CD133 was lower in grade II/III meningiomas, while cells positive for SOX2 and negative CD133 increased in frequency. The increase in the later was particularly noted in the recurrent tumor Jed49_MN. The fraction of Ki67+ cells that were Nestin negative were more frequent in grade II/III meningiomas, even though Nestin expression tended to slightly increase with grade [28]. Together, these observations may be explained by the CSC clonal evolution theory, where for example, cells positive for SOX2 and CD133 could occur at early development and diverge later to partner with other SC-related genes [79]. In addition, they highlight in vitro and in situ differences in the expression of CSCs markers that may reflect epigenetic changes, influenced by the microenvironment.

The analysis of a single marker throughout the consecutive sections along a depth of $32 \mu \mathrm{m}$ indicated a strong correlation of expression for both adjacent and distal sections of meningioma tissues. Basic analysis locating CSC niches across consecutive sections has been attempted previously in breast cancer tissues [80, 81]; however, no correlation of expression was studied. Spearman's Rho factor indicated a highly significant correlation between the expressions of Vimentin and SSEA4, and the expressions of CD133 and GFAP. The co-expression of SSEA4 and Vimentin has been observed in multipotent mesenchymal SCs and in postnatal periodontal ligament (PDL)-derived SCs (PDLSC) [11, 82]. CD133 and GFAP 


\begin{tabular}{|c|c|c|c|c|c|c|c|c|c|c|c|c|c|c|c|}
\hline Marker & Nestin+ & Ki67+ & CD133+ & Sox $2+$ & Vimentin+ & FZD9+ & SSEA4+ & Olig2+ & GFAP+ & BIIITubulin+ & $\begin{array}{c}\text { Nestin+ } \\
\text { Ki67+ }\end{array}$ & $\begin{array}{c}\text { CD133+ } \\
\text { Sox2+ }\end{array}$ & $\begin{array}{c}\text { Vimentin+ } \\
\text { FZD9+ }\end{array}$ & $\begin{array}{c}\text { SSEA4+ } \\
\text { Sox2+ }\end{array}$ & $\begin{array}{c}\text { SSEA4+ } \\
\text { Olig2+ }\end{array}$ \\
\hline$\overline{\text { Nestin+ }}$ & 1.000 & \begin{tabular}{|l|}
.379 \\
\end{tabular} & .504 & .289 & .500 & .504 & $.636^{*}$ & \begin{tabular}{|l|l|}
.075 \\
\end{tabular} & .457 & .229 & $.692^{* * *}$ & .356 & .504 & .171 & .164 \\
\hline Ki67+ & & 1.000 & .011 & .239 & .025 & .429 & .146 & .236 & .311 & .307 & $.842^{* *}$ & .107 & .429 & .371 & .146 \\
\hline CD133+ & & & 1.000 & .496 & .239 & .286 & $.561^{*}$ & .168 & $.657^{* *}$ & .364 & .190 & $.727^{* *}$ & .286 & .464 & .261 \\
\hline Sox $2+$ & & & & 1.000 & .196 & $.589^{*}$ & .343 & .425 & .232 & $.557^{*}$ & .405 & $.894^{* * *}$ & $.589^{*}$ & $.932^{* *}$ & $.518^{*}$ \\
\hline$\overline{\text { Vimentin+ }}+$ & & & & & 1.000 & $.529^{*}$ & $.689^{* *}$ & .489 & .282 & .271 & .222 & .202 & $.529^{*}$ & .068 & $.611^{*}$ \\
\hline FZD9+ & & & & & & 1.000 & .282 & $.532^{*}$ & .361 & .404 & $.516^{*}$ & .411 & $1.000^{* *}$ & $.568^{*}$ & $.568^{*}$ \\
\hline SSEA4+ & & & & & & & 1.000 & .357 & .350 & .489 & .409 & $.540^{*}$ & .282 & .254 & $.514^{*}$ \\
\hline Olig2+ & & & & & & & & 1.000 & .429 & .396 & .258 & .463 & $.532^{*}$ & .496 & $.957^{* *}$ \\
\hline GFAP+ & & & & & & & & & 1.000 & .350 & .344 & .356 & .361 & .279 & .396 \\
\hline BIIITubulin+ & & & & & & & & & & 1.000 & .444 & $.574^{*}$ & .404 & $.532^{*}$ & .443 \\
\hline Nestin+Ki67+ & & & & & & & & & & & 1.000 & .335 & $.516^{*}$ & .466 & .276 \\
\hline CD133+Sox2+ & & & & & & & & & & & & 1.000 & .411 & $.847^{* *}$ & $.556^{*}$ \\
\hline Vimentin+FZD9+ & & & & & & & & & & & & & 1.000 & $.568^{*}$ & $.568^{*}$ \\
\hline SSEA4+Sox $2+$ & & & & & & & & & & & & & & 1.000 & $.561^{*}$ \\
\hline SSEA4+Olig2+ & & & & & & & & & & & & & & & 1.000 \\
\hline
\end{tabular}

b

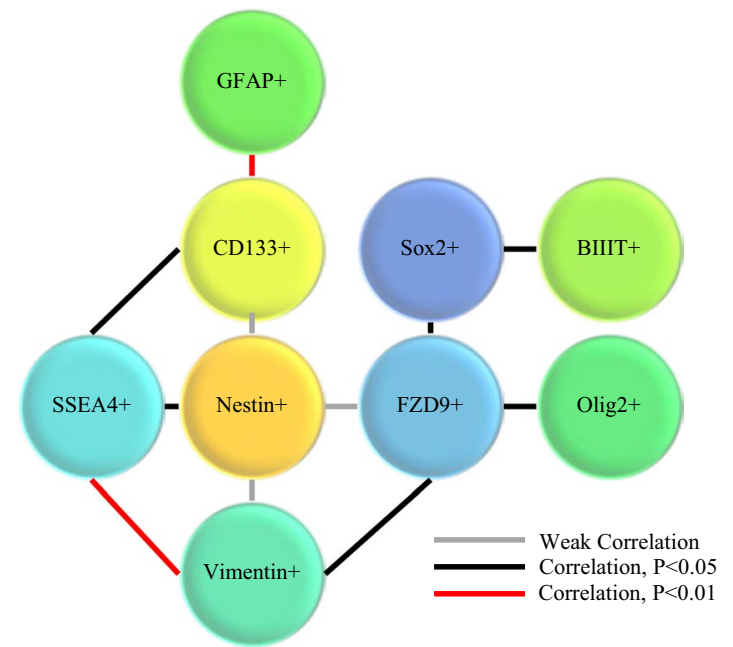

c

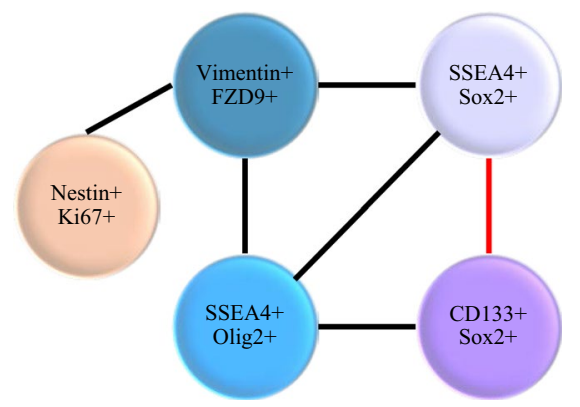

Fig. 5 Correlation trends between the expressions of different markers across consecutive tissues. a A list showing Spearman's Rho correlation coefficients. ${ }^{*}$ Correlation is significant at the 0.05 level (2-tailed). ${ }^{* *}$ Correlation is significant at the 0.01 level (2-tailed). b Illustrations of the strength of correlations between different single markers, and c co-stained markers

co-expression has been detected in glioneuronal tumors [83], glioblastoma cells [84], and activated B1 astrocytes $[85,86]$. Such correlation implicates activated B1 astrocytes' expression-like program in at least a fraction of meningioma cells. Significant correlations were also observed for the expressions of SSEA4 with CD133 or Nestin, FZD9 with Vimentin or SOX2 or Olig2, and SOX2 with BIIIT. Enrichment for SSEA4 and CD133-positive cells from cord blood marked very small embryonic-like stem cells (VSELs) that have high telomerase activity and express pluripotent SC markers OCT4, SSEA4, NANOG, and SOX2 [87]. Similarly, the co-expression of SSEA4 and Nestin has been observed in human umbilical cord matrix-derived mesenchymal SCs [88]. The presence of Nestin-positive proliferating cells also correlates with the presence of Vimentin+FZD9+ cells. Co-expression of FZD9 and Nestin has been observed in neural stem progenitor, derived from patients with Williams syndrome, a developmental disorder caused by mutations in chromosome 7 [89]. The correlation of FZD9 with SOX2 is perhaps not surprising, giving that they are both part of the WNT signaling pathway, a pathway that is activated in some meningiomas [37]. Perhaps more surprising is the correlation between SOX2 and BIIT. This combination has been implicated in taxane resistance for patients with stage III ovarian epithelial cancer [90] and observed in GBM cell lines [91]. Interestingly, the expression of Ki67 alone does not correlate with any particular marker, suggesting that proliferating cells belong to a heterogeneous population of clones. Alternatively, cells may be exiting SC-like status to divide.

An increase in the tumor heterogeneity of CNSTs has long been associated with aggressiveness, resistance, and reoccurrence [79, 92-96]. Recent studies have addressed heterogeneity using novel and challenging approaches [62, 97]; however, very few are documented 


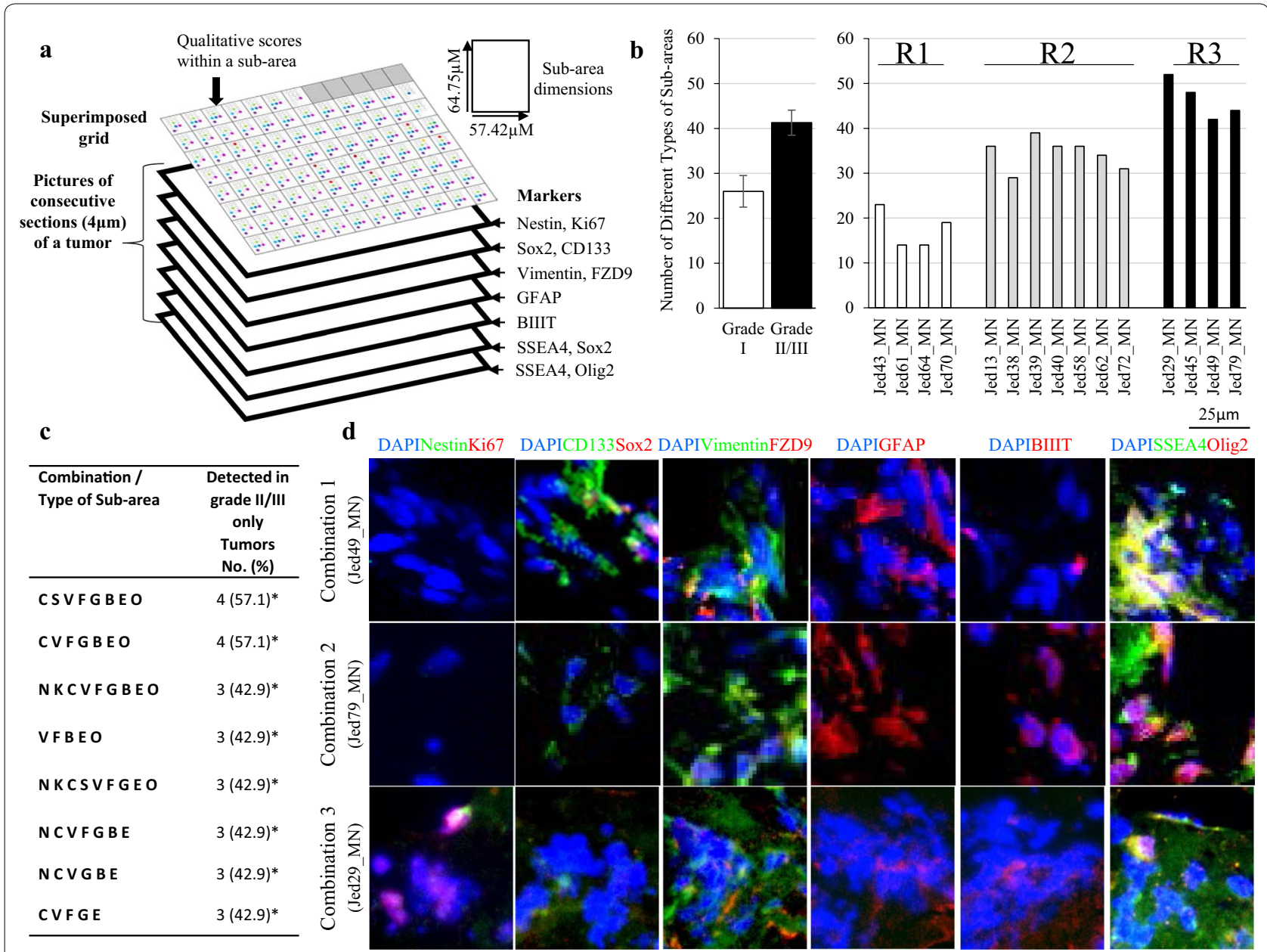

Fig. 6 Hetero-regional expression analysis of sub-areas across consecutive sections for all meningioma tissues. a A diagram depicting consecutive sectioning and immunofluorescence staining for each section. $\mathbf{b}$ Bar graphs showing the number of different types of sub-areas for all tumors separated into significantly differential groups (R1, R2, R3) or grades (grade I, grade II/III). c Regions that significantly frequently occurred in grade II/ III but never in grade I meningiomas. $\mathbf{d}$ Representative immunofluorescence images for consecutive sections for significantly frequently occurring combinations in grade II/III meningiomas. Sections were double stained for Ki67 (red) with Nestin (green), SOX2 (red) with CD133 (green), Vimentin (green) with FZD9 (red), SSEA4 (green) with SOX2 (red), and SSEA4 (green) with Olig2 (red), each with DAPI (blue). Single staining of GFAP (red) and BlllTubulin (red) is also shown. All images were taken at $\times 20$

for meningiomas. In situ analysis can harness the spatial information of tumor heterogeneity [98, 99], in particular, the analysis of consecutive sections that provide three dimension spatial information. While the association of CSCs heterogeneity in CNSTs with high tumor aggressiveness is currently being debated [100, 101], the data presented here show a clear difference in the hetero-regional expression of the investigated markers for grade I and grade II/III meningiomas. Interestingly, however, hetero-regional expression could be detected even in grade I tumors. In addition, particular combinations occur frequently in grade II/III and never in grade
I meningiomas. Both observations could be explained by the CSC evolution hypothesis, where CSCs acquire new changes in the early development of disease and continue to acquire new changes with progressive disease [23, 95]. Whether the identified combinations detected only in grade II/III meningiomas can be used for predictive diagnostic purpose remains to be seen, as a larger cohort of high grade meningiomas is needed. Nevertheless, these results highlight that similarly to neural SC markers [85], and due to CSC heterogeneity, markers must be used in combinations to ensure proper CSC identification. Any aspirations to develop targeted therapies for CSCs are dependent on accurate identifications of all heterogeneous populations. 


\section{Conclusion}

Meningiomas present a unique human model for exploring CSCs progression in CNSTs, as they encompass a variety of tumors that differ in growth rates and the capacity to reoccur or metastasize. Using a potentially widely applicable method for analyzing consecutive sections, our study presents a comprehensive differential analysis of the three dimensional spatial distribution of CSC markers, their co-expression, and their correlation in relation to grade. The distribution and the level of expression for individual CSCs markers in meningiomas are variable between patients, however, collective analysis of markers indicates a complex spatial nature that is particularly associated with higher grades. Thus, results strongly support the notion of heterogeneous populations of CSCs, even in grade I meningiomas, and call for the use of multiple markers for the accurate identification of individual CSC subgroups. Such identification will lead to practical clinical diagnostic protocols that can quantitate CSCs, predict tumor recurrence, assist in guiding treatment selection for inoperable tumors, and improve follow up of therapy.

\section{Additional files}

Additional file 1: Table S1. The clinical profiles for the included patients and their tumors' histopathological features.

Additional file 2: Figure S1. H\&E images for different morphological variants and atypical features for meningiomas used in this study. A. Images showing WHO classified morphological features for different meningioma variants. Meningothelial (Jed39_MN) with neoplastic growth of syncytial epithelial cells with indistinct cell borders arranged in whorls; fibroblastic (Jed40_MN) showing spindle cells with indistinct cell boundaries running in fascicle; transitional (Jed38_MN) with ratios of meningothelial to fibroblastic patterns 40:60; psammomatous (Jed43_MN) composed of whorled clusters of spindle cells with numerous psammoma bodies; chordoid (Jed79_MN), Cords of epithelioid cells with focal clear to foamy cytoplasm on myxoid stroma.; rhabdoid (Jed29_MN) showing hypercellular sheets with rhabdoid morphology. B. Tumors with atypical features. Images show patternless growth (sheeting) in Jed72 MN, necrosis and small cells with high nuclear to cytoplasm ratio in Jed58_MN, and brain invasion in Jed13_MN. Magnifications are indicated above images.

Additional file 3: Table S2. Differentially expressed cancer driver genes [66] in individual tumors compared with three normal brain sample data sets, referenced in Gene Expression Omnibus (GEO) submission GSE77259. Values were generated from previously published data sets $[64,65]$ using Transcriptome Analysis Console v. 4.0

Additional file 4: Figure S2. A bar graph showing averages of counts for Ki67 stained sections collected using manual counting or automated counting in Image J software.

Additional file 5: Figure S3. A. Representative immunofluorescence images for consecutive sections for the grade I Jed64_MN meningioma. Sections were double stained for Ki67 (red) with Nestin (green), SOX2 (red) with CD133 (green), Vimentin (green) with FZD9 (red), SSEA4 (green) with SOX2 (red), and SSEA4 (green) with Olig2 (red), and each section was stained with DAPI (blue). Single staining of GFAP (red) or BlllTubulin (red) is also shown. All images were taken at 20x. B. A grid used as a repository of information for categorical staining is shown with a color-coded legend and size dimensions for sub-areas.
Additional file 6: Figure S4. A. Representative immunofluorescence images for consecutive sections for the grade III Jed29_MN meningioma. Sections were double stained for Ki67 (red) with Nestin (green), SOX2 (red) with CD133 (green), Vimentin (green) with FZD9 (red), SSEA4 (green) with SOX2 (red), and SSEA4 (green) with Olig2 (red), and each section was stained with DAPI (blue). Single staining of GFAP (red) or BlllTubulin (red) is also shown. All images were taken at 20x. B. A grid used as a repository of information for categorical staining is shown with a color-coded legend and size dimensions for sub-areas.

Additional file 7: Table S3. All combinations of markers observed in consecutive sections and their frequencies in all 15 meningioma samples.

\section{Abbreviations}

CNSTs: central nervous system tumors; WHO: World Health Organization; CSCs: cancer stem cells; KAUH: King Abdulaziz University Hospital; FZD9: Frizzled9; GFAP: glial fibrillary acidic protein; SSEA4: specific embryonic antigen-4; $\beta I I-$ tubulin/ßIIIT: beta III tubulin; PIK3: phosphoinositide 3-kinase; SMO: G proteincoupled receptor smoothened; GSL: glycosphingolipid; PDMP: phenyl-2-decanoylamino-3-morphilino-1-propranol; bHLH: basic helix-loop-helix; PBS: phosphate buffered saline; PBST: Triton X-100 in PBS; NGS: normal goat serum; SPSS: Statistical Analysis Software Package; ANOVA: analysis of variance; SVZ: subventricular zone; PDLSC: postnatal periodontal ligament (PDL)-derived SC; VSELs: very small embryonic-like stem cells.

\section{Authors' contributions}

The tissues were cut and stained by MA, HA, AS, and MS. The counting was performed by $\mathrm{MA}, \mathrm{HA}$, and $\mathrm{DH}$. The confirmation of counting was performed by $\mathrm{DH}, \mathrm{HS}$, and FA. The histopathological classifications of tumors were done by FA. The conception and design was set by $M B, S B, A C, A C, A A$, and $D H$. $\mathrm{HS}$ and $\mathrm{DH}$ wrote the manuscript. All authors read and approved the final manuscript.

\section{Author details}

${ }^{1}$ Centre of Innovation for Personalized Medicine, King Abdulaziz University, Jeddah 21589, Saudi Arabia. ${ }^{2}$ King Fahd Medical Research Center, King Abdulaziz University, P.O. Box. 80216, Jeddah 21589, Saudi Arabia. ${ }^{3}$ Division of Neurosurgery, King Abdulaziz University, Jeddah 21589, Saudi Arabia. ${ }^{4}$ Pathology Department, King Abdulaziz University, Jeddah 21589, Saudi Arabia. ${ }^{5}$ Galician Foundation of Genomic Medicine-SERGAS, University of Santiago de Compostela, 15706 Santiago de Compostela, Spain. ${ }^{6}$ Center of Excellence in Genomic Medicine, King Abdulaziz University, Jeddah 21589, Saudi Arabia. ${ }^{7}$ Faculty of Applied Medical Sciences, King Abdulaziz University, Jeddah 21589, Saudi Arabia.

\section{Acknowledgements}

The authors thank Dr. Ghazi Damanhouri, Prof. E. Azhar, Mr. M.Z. Elassouli, Mr. A. Shareef, and Dr. A. Mirza in King Fahd Medical Research Center, King Abdulaziz University for their support and Dr. A. Dallol in the Center of Personalized Medicine, King Abdulaziz University for his support. The authors also thank the patients and their families for their tissue donations.

\section{Competing interests}

The authors declare that they have no competing interests.

\section{Availability of data and materials}

Raw data that support the findings of this study are available from D. Hussein, but restrictions apply to the availability of these data, which were used under license for the current study, and thus are not publicly available. Data are, however, available from the authors upon reasonable request and with the permission of $D$. Hussein.

\section{Consent for publication}

Not applicable.

\section{Ethics approval and consent to participate}

This work was approved by the Ethical Board of King Abdulaziz University Hospital (KAUH) (Board registration number at the National Committee of Bio. and 
Med. Ethics is HA-02-J-008) (Project Reference No. 976-12). A signed informed consent designed according to the Declaration of Helsinki was obtained for each donated tumor sample.

\section{Funding}

This work was funded by the Dean of Scientific Research, King Abdulaziz University, KSA (HiCi 1434-117-11).

\section{Publisher's Note}

Springer Nature remains neutral with regard to jurisdictional claims in published maps and institutional affiliations.

Received: 4 March 2018 Accepted: 15 May 2018

Published online: 25 May 2018

\section{References}

1. Lym RL, Ostrom QT, Kruchko C, Couce M, Brat DJ, Louis DN, BarnholtzSloan JS. Completeness and concordancy of WHO grade assignment for brain and central nervous system tumors in the United States, 2004-2011. J Neurooncol. 2015;123(1):43-51.

2. Khan I, Bangash M, Baeesa S, Jamal A, Carracedo A, Alghamdi F, Qashqari H, Abuzenadah A, AlQahtani M, Damanhouri G, et al. Epidemiological trends of histopathologically WHO classified CNS tumors in developing countries: systematic review. Asian Pac J Cancer Prev. 2015;16(1):205-16.

3. Preusser M, Brastianos PK, Mawrin C. Advances in meningioma genetics: novel therapeutic opportunities. Nat Rev Neurol. 2018;14(2):106-15.

4. Brastianos PK, Horowitz PM, Santagata S, Jones RT, McKenna A, Getz G, Ligon KL, Palescandolo E, Van Hummelen P, Ducar MD, et al. Genomic sequencing of meningiomas identifies oncogenic SMO and AKT1 mutations. Nat Genet. 2013;45(3):285-9.

5. Clark VE, Erson-Omay EZ, Serin A, Yin J, Cotney J, Ozduman K, Avsar T, Li J, Murray PB, Henegariu O, et al. Genomic analysis of non-NF2 meningiomas reveals mutations in TRAF7, KLF4, AKT1, and SMO. Science. 2013;339(6123):1077-80.

6. Abedalthagafi M, Bi WL, Aizer AA, Merrill PH, Brewster R, Agarwalla PK, Listewnik ML, Dias-Santagata D, Thorner AR, Van Hummelen P, et al. Oncogenic PI3K mutations are as common as AKT1 and SMO mutations in meningioma. Neuro Oncol. 2016;18(5):649-55.

7. Saraf S, McCarthy BJ, Villano JL. Update on meningiomas. Oncologist. 2011;16(11):1604-13.

8. Linsler S, Kraemer D, Driess C, Oertel J, Kammers K, Rahnenfuhrer J, Ketter R, Urbschat S. Molecular biological determinations of meningioma progression and recurrence. PLoS ONE. 2014;9(4):e94987.

9. Shivapathasundram G, Wickremesekera AC, Tan ST, Itinteang T. Tumour stem cells in meningioma: a review. J Clin Neurosci. 2018;47:66-71.

10. Hu D, Wang X, Mao Y, Zhou L. Identification of CD105 (endoglin)positive stem-like cells in rhabdoid meningioma. J Neurooncol. 2012;106(3):505-17.

11. Lim HY, Kim KM, Kim BK, Shim JK, Lee JH, Huh YM, Kim SH, Kim EH, Park EK, Shim KW, et al. Isolation of mesenchymal stem-like cells in meningioma specimens. Int J Oncol. 2013;43(4):1260-8.

12. Rath P, Miller DC, Litofsky NS, Anthony DC, Feng Q, Franklin C, Pei L, Free A, Liu J, Ren M, et al. Isolation and characterization of a population of stem-like progenitor cells from an atypical meningioma. Exp Mol Pathol. 2011;90(2):179-88.

13. Tang $\mathrm{H}$, Gong $Y$, Mao $Y$, Xie $Q$, Zheng M, Wang D, Zhu H, Wang X, Chen $\mathrm{H}$, Chen $\mathrm{X}$, et al. CD133-positive cells might be responsible for efficient proliferation of human meningioma cells. Int J Mol Sci. 2012;13(5):6424-39.

14. Freitag D, McLean AL, Simon M, Koch A, Grube S, Walter J, Kalff R, Ewald C. NANOG overexpression and its correlation with stem cell and differentiation markers in meningiomas of different $\mathrm{WHO}$ grades. Mol Carcinog. 2017:56(8):1953-64

15. Li Z. CD133: a stem cell biomarker and beyond. Exp Hematol Oncol. 2013:2(1):17.

16. Li Q, Rycaj K, Chen X, Tang DG. Cancer stem cells and cell size: a causal link? Semin Cancer Biol. 2015:35:191-9.
17. Taieb N, Maresca M, Guo XJ, Garmy N, Fantini J, Yahi N. The first extracellular domain of the tumour stem cell marker CD133 contains an antigenic ganglioside-binding motif. Cancer Lett. 2009;278(2):164-73.

18. Wu X, Wu F, Xu D, Zhang T. Prognostic significance of stem cell marker CD133 determined by promoter methylation but not by immunohistochemical expression in malignant gliomas. J Neurooncol. 2016:127(2):221-32

19. Yan X, Ma L, Yi D, Yoon JG, Diercks A, Foltz G, Price ND, Hood LE, Tian Q. A CD133-related gene expression signature identifies an aggressive glioblastoma subtype with excessive mutations. Proc Natl Acad Sci USA. 2011;108(4):1591-6.

20. Metellus P, Nanni-Metellus I, Delfino C, Colin C, Tchogandjian A, Coulibaly B, Fina F, Loundou A, Barrie M, Chinot $O$, et al. Prognostic impact of CD133 mRNA expression in 48 glioblastoma patients treated with concomitant radiochemotherapy: a prospective patient cohort at a single institution. Ann Surg Oncol. 2011;18(10):2937-45.

21. Wu B, Sun C, Feng F, Ge M, Xia L. Do relevant markers of cancer stem cells CD133 and Nestin indicate a poor prognosis in glioma patients? A systematic review and meta-analysis. J Exp Clin Cancer Res. 2015:34:44-55.

22. Khan I, Baeesa S, Bangash M, Schulten HJ, Alghamdi F, Qashqari H, Madkhali N, Carracedo A, Saka M, Jamal A, et al. Pleomorphism and drug resistant cancer stem cells are characteristic of aggressive primary meningioma cell lines. Cancer Cell Int. 2017;17:72-85.

23. Prieto-Vila M, Takahashi RU, Usuba W, Kohama I, Ochiya T. Drug resistance driven by cancer stem cells and their niche. Int J Mol Sci. 2017;18(12):E2574

24. Ishiwata T, Teduka K, Yamamoto T, Kawahara K, Matsuda Y, Naito Z. Neuroepithelial stem cell marker nestin regulates the migration, invasion and growth of human gliomas. Oncol Rep. 2011;26(1):91-9.

25. Liu J, Reeves C, Jacques T, McEvoy A, Miserocchi A, Thompson P, Sisodiya S, Thom M. Nestin-expressing cell types in the temporal lobe and hippocampus: morphology, differentiation, and proliferative capacity. Glia. 2018;66(1):62-77.

26. Neradil J, Veselska R. Nestin as a marker of cancer stem cells. Cancer Sci. 2015;106(7):803-11.

27. Reimer R, Helmbold H, Szalay B, Hagel C, Hohenberg H, Deppert W, Bohn W. Nestin modulates glucocorticoid receptor function by cytoplasmic anchoring. PLOS ONE. 2009;4(6):e6084

28. Galani V, Alexiou GA, Miliaras G, Dimitriadis E, Triantafyllou E, Galani A Goussia A, Kanavaros P, Trangas T. Expression of stem cell marker nestin and microRNA-21 in meningiomas. Turk Neurosurg. 2015:25(4):574-7.

29. Wuebben EL, Rizzino A. The dark side of SOX2: cancer-a comprehensive overview. Oncotarget. 2017;8(27):44917-43.

30. Annovazzi L, Mellai M, Caldera V, Valente G, Schiffer D. SOX2 expression and amplification in gliomas and glioma cell lines. Cancer Genomics Proteomics. 2011;8(3):139-47.

31. Alonso MM, Diez-Valle R, Manterola L, Rubio A, Liu D, Cortes-Santiago N Urquiza L, Jauregi P, Lopez de Munain A, Sampron N, et al. Genetic and epigenetic modifications of Sox 2 contribute to the invasive phenotype of malignant gliomas. PLoS ONE. 2011;6(11):e26740.

32. Favaro R, Appolloni I, Pellegatta S, Sanga AB, Pagella P, Gambini E, Pisati F, Ottolenghi S, Foti $M$, Finocchiaro $G$, et al. Sox2 is required to maintain cancer stem cells in a mouse model of high-grade oligodendroglioma. Cancer Res. 2014;74(6):1833-44.

33. Gangemi RM, Griffero F, Marubbi D, Perera M, Capra MC, Malatesta P, Ravetti GL, Zona GL, Daga A, Corte G. SOX2 silencing in glioblastoma tumor-initiating cells causes stop of proliferation and loss of tumorigenicity. Stem Cells. 2009;27(1):40-8

34. Song WS, Yang YP, Huang CS, Lu KH, Liu WH, Wu WW, Lee YY, Lo WL, Lee SD, Chen YW, et al. Sox2, a stemness gene, regulates tumor-initiating and drug-resistant properties in CD133-positive glioblastoma stem cells. J Chin Med Assoc. 2016;79(10):538-45.

35. Simonetti M, Agarwal N, Stosser S, Bali KK, Karaulanov E, Kamble R, Pospisilova B, Kurejova M, Birchmeier W, Niehrs C, et al. Wnt-Fzd signaling sensitizes peripheral sensory neurons via distinct noncanonical pathways. Neuron. 2014;83(1):104-21.

36. Schenkelaars Q, Fierro-Constain L, Renard E, Hill AL, Borchiellini C. Insights into Frizzled evolution and new perspectives. Evol Dev. 2015;17(2):160-9 
37. Pecina-Slaus N, Kafka A, Varosanec AM, Markovic L, Krsnik Z, Njiric N, Mrak G. Expression patterns of Wnt signaling component, secreted frizzledrelated protein 3 in astrocytoma and glioblastoma. Mol Med Rep. 2016;13(5):4245-51

38. Generoso SF, Giustiniano M, La Regina G, Bottone S, Passacantilli S, Di Maro S, Cassese H, Bruno A, Mallardo M, Dentice M, et al. Pharmacological folding chaperones act as allosteric ligands of Frizzled4. Nat Chem Biol. 2015;11(4):280-6.

39. Tondeur S, Assou S, Nadal L, Hamamah S, De Vos J. Biology and potential of human embryonic stem cells. Ann Biol Clin (Paris). 2008;66(3):241-7.

40. Harichandan A, Sivasubramaniyan K, Hennenlotter J, Schwentner C, Stenzl A, Buhring HJ. Isolation of adult human spermatogonial progenitors using novel markers. J Mol Cell Biol. 2013;5(5):351-3.

41. Virant-Klun I, Skutella T, Hren M, Gruden K, Cvjeticanin B, Vogler A, Sinkovec J. Isolation of small SSEA-4-positive putative stem cells from the ovarian surface epithelium of adult human ovaries by two different methods. Biomed Res Int. 2013;2013:690415.

42. Lou YW, Wang PY, Yeh SC, Chuang PK, Li ST, Wu CY, Khoo KH, Hsiao M, Hsu TL, Wong CH. Stage-specific embryonic antigen-4 as a potential therapeutic target in glioblastoma multiforme and other cancers. Proc Natl Acad Sci USA. 2014;111(7):2482-7.

43. Noto Z, Yoshida T, Okabe M, Koike C, Fathy M, Tsuno H, Tomihara K, Arai N, Noguchi M, Nikaido T. CD44 and SSEA-4 positive cells in an oral cancer cell line HSC-4 possess cancer stem-like cell characteristics. Oral Oncol. 2013;49(8):787-95.

44. Gottschling S, Jensen K, Warth A, Herth FJ, Thomas M, Schnabel PA, Herpel E. Stage-specific embryonic antigen-4 is expressed in basaloid lung cancer and associated with poor prognosis. Eur Respir J. 2013:41(3):656-63.

45. Kavitha CV, Jain AK, Agarwal C, Pierce A, Keating A, Huber KM, Serkova NJ, Wempe MF, Agarwal R, Deep G. Asiatic acid induces endoplasmic reticulum stress and apoptotic death in glioblastoma multiforme cells both in vitro and in vivo. Mol Carcinog. 2015;54(11):1417-29.

46. Aloia A, Petrova E, Tomiuk S, Bissels U, Deas O, Saini M, Zickgraf FM, Wagner S, Spaich S, Sutterlin M, et al. The sialyl-glycolipid stage-specific embryonic antigen 4 marks a subpopulation of chemotherapy-resistant breast cancer cells with mesenchymal features. Breast Cancer Res. 2015;17(1):146-62.

47. Sivasubramaniyan K, Harichandan A, Schilbach K, Mack AF, Bedke J, Stenzl A, Kanz L, Niederfellner G, Buhring HJ. Expression of stagespecific embryonic antigen-4 (SSEA-4) defines spontaneous loss of epithelial phenotype in human solid tumor cells. Glycobiology. 2015;25(8):902-17.

48. Meijer DH, Kane MF, Mehta S, Liu H, Harrington E, Taylor CM, Stiles CD, Rowitch DH. Separated at birth? The functional and molecular divergence of OLIG1 and OLIG2. Nat Rev Neurosci. 2012;13(12):819-31.

49. Tsigelny IF, Kouznetsova VL, Lian N, Kesari S. Molecular mechanisms of OLIG2 transcription factor in brain cancer. Oncotarget. 2016;7(33):53074-101.

50. Mateo JL, van den Berg DL, Haeussler M, Drechsel D, Gaber ZB, Castro DS, Robson P, Lu QR, Crawford GE, Flicek P, et al. Characterization of the neural stem cell gene regulatory network identifies OLIG2 as a multifunctional regulator of self-renewal. Genome Res. 2015;25(1):41-56.

51. Motomura K, Natsume A, Watanabe R, Ito I, Kato Y, Momota H, Nishikawa R, Mishima K, Nakasu Y, Abe T, et al. Immunohistochemical analysis-based proteomic subclassification of newly diagnosed glioblastomas. Cancer Sci. 2012;103(10):1871-9.

52. Nevo I, Woolard K, Cam M, Li A, Webster JD, Kotliarov Y, Kim HS, Ahn S, Walling J, Kotliarova S, et al. Identification of molecular pathways facilitating glioma cell invasion in situ. PLoS ONE. 2014;9(11):e111783.

53. Matsumoto S, Banine F, Feistel K, Foster S, Xing R, Struve J, Sherman LS. Brg1 directly regulates Olig2 transcription and is required for oligodendrocyte progenitor cell specification. Dev Biol. 2016;413(2):173-87.

54. Hol EM, Capetanaki Y. Type III intermediate filaments desmin, glial fibrillary acidic protein (GFAP), vimentin, and peripherin. Cold Spring Harb Perspect Biol. 2017;9(12):a021642.

55. Bouamrani A, Ramus C, Gay E, Pelletier L, Cubizolles M, Brugiere S, Wion D, Berger F, Issartel JP. Increased phosphorylation of vimentin in noninfiltrative meningiomas. PLoS ONE. 2010;5(2):e9238.
56. van den Berge SA, Middeldorp J, Zhang CE, Curtis MA, Leonard BW, Mastroeni D, Voorn P, van de Berg WD, Huitinga I, Hol EM. Longterm quiescent cells in the aged human subventricular neurogenic system specifically express GFAP-delta. Aging Cell. 2010;9(3):313-26.

57. Brehar FM, Arsene D, Brinduse LA, Gorgan MR. Immunohistochemical analysis of GFAP-delta and nestin in cerebral astrocytomas. Brain Tumor Pathol. 2015;32(2):90-8.

58. Mariani M, Karki R, Spennato M, Pandya D, He S, Andreoli M, Fiedler P, Ferlini C. Class III beta-tubulin in normal and cancer tissues. Gene. 2015;563(2):109-14.

59. Max N, Hu C, Kreylos O, Crivelli S. BuildBeta-a system for automatically constructing beta sheets. Proteins. 2010;78(3):559-74.

60. Person F, Wilczak W, Hube-Magg C, Burdelski C, Moller-Koop C, Simon R, Noriega M, Sauter G, Steurer S, Burdak-Rothkamm S, et al. Prevalence of betalll-tubulin (TUBB3) expression in human normal tissues and cancers. Tumour Biol. 2017;39(10):1010428317712166.

61. Ludwig K, Kornblum HI. Molecular markers in glioma. J Neurooncol. 2017;134(3):505-12.

62. Patel AP, Tirosh I, Trombetta JJ, Shalek AK, Gillespie SM, Wakimoto H, Cahill DP, Nahed BV, Curry WT, Martuza RL, et al. Single-cell RNA-seq highlights intratumoral heterogeneity in primary glioblastoma. Science. 2014;344(6190):1396-401.

63. Malta TM, Sokolov A, Gentles AJ, Burzykowski T, Poisson L, Weinstein JN, Kaminska B, Huelsken J, Omberg L, Gevaert O, et al. Machine learning identifies stemness features associated with oncogenic dedifferentiation. Cell. 2018;173(2):338-54.

64. Schulten HJ, Hussein D, Al-Adwani F, Karim S, Al-Maghrabi J, Al-Sharif M, Jamal A, Al-Ghamdi F, Baeesa SS, Bangash M, et al. Microarray expression data identify DCC as a candidate gene for early meningioma progression. PLoS ONE. 2016;11(4):e0153681.

65. Schulten HJ, Bangash M, Karim S, Dallol A, Hussein D, Merdad A, Al-Thoubaity FK, Al-Maghrabi J, Jamal A, Al-Ghamdi F, et al. Comprehensive molecular biomarker identification in breast cancer brain metastases. J Transl Med. 2017;15(1):269-88.

66. Bailey MH, Tokheim C, Porta-Pardo E, Sengupta S, Bertrand D, Weerasinghe A, Colaprico A, Wendl MC, Kim J, Reardon B, et al. Comprehensive characterization of cancer driver genes and mutations. Cell. 2018;173(2):371-85

67. Zhang M, Song T, Yang L, Chen R, Wu L, Yang Z, Fang J. Nestin and CD133: valuable stem cell-specific markers for determining clinical outcome of glioma patients. J Exp Clin Cancer Res. 2008;27:85-91.

68. Wang B, Li M, Wu Z, Li X, Li YU, Shi X, Cheng W. Associations between SOX2 and miR-200b expression with the clinicopathological characteristics and prognosis of patients with glioma. Exp Ther Med. 2015;10(1):88-96

69. Pavelin S, Becic K, Forempoher G, Mrklic I, Pogorelic Z, Titlic M, Andelinovic S. Expression of Ki-67 and p53 in meningiomas. Neoplasma. 2013;60(5):480-5.

70. Nayak MT, Singh A, Desai RS, Vanaki SS. Immunohistochemical analysis of vimentin in oral submucous fibrosis. J Cancer Epidemiol. 2013:2013:549041.

71. Shah SM, Kang YJ, Christensen BL, Feng AS, Kollmar R. Expression of Wnt receptors in adult spiral ganglion neurons: frizzled 9 localization at growth cones of regenerating neurites. Neuroscience. 2009;164(2):478-87.

72. Otero JJ, Rowitch D, Vandenberg S. OLIG2 is differentially expressed in pediatric astrocytic and in ependymal neoplasms. J Neurooncol. 2011;104(2):423-38.

73. Roque DM, Buza N, Glasgow M, Bellone S, Bortolomai I, Gasparrini S, Cocco E, Ratner E, Silasi DA, Azodi M, et al. Class III beta-tubulin overexpression within the tumor microenvironment is a prognostic biomarker for poor overall survival in ovarian cancer patients treated with neoadjuvant carboplatin/paclitaxel. Clin Exp Metastasis. 2014;31(1):101-10.

74. Yu Y, Chen Y, Kim B, Wang H, Zhao C, He X, Liu L, Liu W, Wu LM, Mao $M$, et al. Olig2 targets chromatin remodelers to enhancers to initiate oligodendrocyte differentiation. Cell. 2013;152(1-2):248-61.

75. Boulagnon-Rombi C, Fleury C, Fichel C, Lefour S, Marchal Bressenot A, Gauchotte G. Immunohistochemical approach to the differential diagnosis of meningiomas and their mimics. J Neuropathol Exp Neurol. 2017;76(4):289-98. 
76. Hermansen SK, Christensen KG, Jensen SS, Kristensen BW. Inconsistent immunohistochemical expression patterns of four different CD133 antibody clones in glioblastoma. J Histochem Cytochem. 2011;59(4):391-407

77. Albayrak BS, Ismailoglu O, Tanriover G, Cetinalp EN, Demir N. The double immunostaining of CD133 and Ki-67 favours a significant co-localization pattern in fibroblastic subtype of meningiomas. Neurol Neurochir Pol. 2011;45(5):467-73.

78. Petricevic J, Forempoher G, Ostojic L, Mardesic-Brakus S, Andjelinovic S, Vukojevic K, Saraga-Babic M. Expression of nestin, mesothelin and epithelial membrane antigen (EMA) in developing and adult human meninges and meningiomas. Acta Histochem. 2011;113(7):703-11.

79. Brown DV, Filiz G, Daniel PM, Hollande F, Dworkin S, Amiridis S, Kountouri N, Ng W, Morokoff AP, Mantamadiotis T. Expression of CD133 and CD44 in glioblastoma stem cells correlates with cell proliferation, phenotype stability and intra-tumor heterogeneity. PLoS ONE. 2017;12(2):e0172791.

80. Liu Y, Shi J, Chen M, Cao YF, Liu YW, Pan J, Qi ST. Periostin: a novel prognostic predictor for meningiomas. J Neurooncol. 2015;121(3):505-12.

81. Gerdes MJ, Gökmen-Polar Y, Sui Y, Pang AS, LaPlante N, Harris AL, Tan P-H, Ginty F, Badve SS. Single-cell heterogeneity in ductal carcinoma in situ of breast. Mod Pathol. 2017;31(3):406-17.

82. Huang L, Liang J, Geng Y, Tsang WM, Yao X, Jhanji V, Zhang M, Cheung HS, Pang CP, Yam GH. Directing adult human periodontal ligament-derived stem cells to retinal fate. Invest Ophthalmol Vis Sci. 2013;54(6):3965-74.

83. Phi JH, Park SH, Chung CK, Wang KC, Cho BK, Kim SK. Atypical cell clusters expressing both neuronal and oligodendrocytic markers: novel histological pattern of glioneuronal tumors? Pathol Int. 2009;59(10):735-43.

84. Rieske P, Golanska E, Zakrzewska M, Piaskowski S, Hulas-Bigoszewska K, Wolanczyk M, Szybka M, Witusik-Perkowska M, Jaskolski DJ, Zakrzewski $\mathrm{K}$, et al. Arrested neural and advanced mesenchymal differentiation of glioblastoma cells-comparative study with neural progenitors. BMC Cancer. 2009;9:54-68.

85. Mamber C, Kozareva DA, Kamphuis W, Hol EM. Shades of gray: the delineation of marker expression within the adult rodent subventricular zone. Prog Neurobiol. 2013;111:1-16.

86. Platel JC, Bordey A. The multifaceted subventricular zone astrocyte: from a metabolic and pro-neurogenic role to acting as a neural stem cell. Neuroscience. 2016;323:20-8.

87. Shaikh A, Nagvenkar P, Pethe P, Hinduja I, Bhartiya D. Molecular and phenotypic characterization of CD133 and SSEA4 enriched very small embryonic-like stem cells in human cord blood. Leukemia. 2015;29(9):1909-17.

88. Matsuoka Y, Nakatsuka R, Sumide K, Kawamura H, Takahashi M, Fujioka T, Uemura Y, Asano H, Sasaki Y, Inoue M, et al. Prospectively isolated human bone marrow cell-derived MSCs support primitive human CD34-negative hematopoietic stem cells. Stem Cells. 2015;33(5):1554-65
89. Chailangkarn T, Trujillo CA, Freitas BC, Hrvoj-Mihic B, Herai RH, Yu DX, Brown TT, Marchetto MC, Bardy C, McHenry L, et al. A human neurodevelopmental model for Williams syndrome. Nature. 2016;536(7616):338-43.

90. Du J, Li B, Fang Y, Liu Y, Wang Y, Li J, Zhou W, Wang X. Overexpression of class III beta-tubulin, Sox2, and nuclear Survivin is predictive of taxane resistance in patients with stage III ovarian epithelial cancer. BMC Cancer. 2015;15:536-46.

91. Qu J, Rizak JD, Fan Y, Guo X, Li J, Huma T, Ma Y. Establishment and partial characterization of a human tumor cell line, GBM-HSF, from a glioblastoma multiforme. Hum Cell. 2014;27(3):129-36.

92. Hsieh JJ, Manley BJ, Khan N, Gao J, Carlo MI, Cheng EH. Overcome tumor heterogeneity-imposed therapeutic barriers through convergent genomic biomarker discovery: a braided cancer river model of kidney cancer. Semin Cell Dev Biol. 2017;64:98-106.

93. Azar S, Leventoux N, Ripoll C, Rigau V, Goze C, Lorcy F, Bauchet L, Duffau H, Guichet PO, Rothhut B, et al. Cellular and molecular characterization of IDH1-mutated diffuse low grade gliomas reveals tumor heterogeneity and absence of EGFR/PDGFRalpha activation. Glia. 2018:66(2):239-55.

94. Irvin DM, McNeill RS, Bash RE, Miller CR. Intrinsic astrocyte heterogeneity influences tumor growth in glioma mouse models. Brain Pathol. 2017;27(1):36-50

95. McGranahan N, Swanton C. Clonal heterogeneity and tumor evolution: past, present, and the future. Cell. 2017;168(4):613-28.

96. Welker AM, Jaros BD, An M, Beattie CE. Changes in tumor cell heterogeneity after chemotherapy treatment in a xenograft model of glioblastoma. Neuroscience. 2017;356:35-43.

97. Rosenberg S, Verreault M, Schmitt C, Guegan J, Guehennec J, Levasseur C, Marie Y, Bielle F, Mokhtari K, Hoang-Xuan K, et al. Multi-omics analysis of primary glioblastoma cell lines shows recapitulation of pivotal molecular features of parental tumors. Neuro Oncol. 2017;19(2):219-28.

98. Bolognesi MM, Manzoni M, Scalia CR, Zannella S, Bosisio FM, Faretta M, Cattoretti G. Multiplex staining by sequential immunostaining and antibody removal on routine tissue sections. J Histochem Cytochem. 2017;65(8):431-44.

99. Simmons AJ, Lau KS. Deciphering tumor heterogeneity from FFPE tissues: its promise and challenges. Mol Cell Oncol. 2017;4(1):e1260191.

100. Prasetyanti PR, Medema JP. Intra-tumor heterogeneity from a cancer stem cell perspective. Mol Cancer. 2017:16(1):41-9.

101. Correnti M, Raggi C. Stem-like plasticity and heterogeneity of circulating tumor cells: current status and prospect challenges in liver cancer. Oncotarget. 2017;8(4):7094-115.

\footnotetext{
Ready to submit your research? Choose BMC and benefit from:

- fast, convenient online submission

- thorough peer review by experienced researchers in your field

- rapid publication on acceptance

- support for research data, including large and complex data types

- gold Open Access which fosters wider collaboration and increased citations

- maximum visibility for your research: over $100 \mathrm{M}$ website views per year
}

At BMC, research is always in progress.

Learn more biomedcentral.com/submissions 